\title{
A VERSENGÉS JUTALMAZÁSÁNAK HATÁSA A NYÁLTESZTOSZTERON-SZINTRE ÉS A TELJESÍTMÉNYRE FIATAL FELNŐTT FÉRFIAKBAN: A HIPERVERSENGÉS SZEREPE*
}

\section{NAGY TAMÁS ${ }^{1,2}$ - KOVÁCS J. KRISZTINA ${ }^{3}$ - POLYÁK ÁGNES ${ }^{3}$ - HARMAT LÁSZLÓ ${ }^{4}$ - BÁRDOS GYÖRGY ${ }^{5}$ - FÜLÖP MÁRTA ${ }^{2}$}

${ }^{1}$ ELTE Pszichológia Doktori Iskola

${ }^{2}$ MTA TTK Kognitív Idegtudományi és Pszichológiai Intézet

${ }^{3}$ MTA Kísérleti Orvostudományi Intézet, Molekuláris Neuroendokrinológia Kutatócsoport

${ }^{4}$ Semmelweis Egyetem Magatartástudományi Intézet,

Pszichofiziológiai és Kronobiológiai Kutatócsoport

${ }^{5}$ ELTE Egészségfejlesztési és Sporttudományi Intézet

E-mail:nagy.tamas@ppk.elte.hu; kovacs.krisztina@koki.mta.hu;

polyak.agnes@koki.mta.hu; laszloharmat@yahoo.com; bardos.gyorgy@ppk.elte.hu; martafulop@yahoo.com

Beérkezett: 2014. október 10. - Elfogadva: 2014. december 20.

Korábbi kutatások megmutatták, hogy versengő helyzetben a nagyobb jutalom megnövekedett fiziológiai arousallal jár. Mégis kevés tanulmány érintette a jutalmazás hatását a tesztoszteron (T) szintre, annak ellenére, hogy ez a hormon érzékenyen reagál a versengő helyzetekre és státuszváltozásokra. A jelen kutatás versengő helyzetben vizsgálta a nyáltesztoszteron és fiziológiai arousal (szívritmus, szívritmusvariabilitás) változásait fiatal felnött férfi mintán $(N=40$, átlag életkor $=21.7 \pm 2.3$ év). A résztvevook egy videojátékban versengtek egymással, ahol a páros egyik tagja nyert, a másik veszitett a képességeknek és eröfeszitésnek megfelelöen. A párosok véletlenszerü csoportositása alapján résztvevök vagy egyenlö pénzjutalmat kaptak, vagy a gyöztes több jutalmat kapott, mint a vesztes (egyenlötlen jutalom). A pszichofiziológiai és endokrinológiai méréseken túl a résztvevők versengéssel kapcsolatos attitüdjeit (hiperversengés, önfejlesztő versengés) és a versengö helyzetben mutatott hangulati változásait is fel-

*A szerzők őszinte köszönetüket fejezik ki dr. Jos Boschnak és dr. Kekecs Zoltánnak, amiért egy korábbi változatára tett megjegyzéseikkel segítették a kézirat jobbá tételét. 
mértük kérdőivek segitségével. Az eredmények azt mutatták, hogy a versengés mindkét csoportban növelte mind a szubjektív, mind a fiziológiai arousalszintjét, ám a jutalom mértéke nem volt szignifikáns hatással a T szintre. A T szint csak a vesztes hiperversengőkben növekedett szignifikánsan. A kompetitív teljesítmény korrelált a gyöztesek és vesztesek $T$ szintjével, illetve annak változásával, alátámasztva azt a korábbi megfigyelést, hogy a versengő teljesítmény és a T egymást kölcsönösen meghatározó kapcsolatban állnak. A kapott eredmények összefüggésben vannak a státuszinstabilitás-hipotézissel.

Kulcsszavak: bio-szociális státuszelmélet, versengés, szívritmus, jutalom, teljesítmény, tesztoszteron, hiperversengés, státuszinstabilitás-hipotézis

\section{BEVEZETÉS}

Az utóbbi évtizedekben nagyszámú kutatás vizsgálta a versengésre adott bio-pszichológiai válaszokat. Ezekben a kutatásokban kiemelt szerep jutott a legfontosabb androgén szteroid hormonnak, a tesztoszteronnak (T). Több tanulmány számolt be emelkedett $T$ szintről a versengésre való felkészülés és a versengő tevékenység alatt (például Bateup, BoOth, Shirtcliffi és Granger, 2002; Mazur, Shelley, Tharp és Kittok, 1989; van der Meij, BuUnk, Almela és Salvador, 2010), valamint arról, hogy a versengés győztesének megnövekedett a T szintje a veszteshez képest (például Costa és SALVAdOr, 2012; MAZur, BoOTH és DabBS Jr, 1992; MCCAUl, GLadue és JopPa, 1992). Ezeket az eredményeket két eltérő, ám egymást kiegészítő elmélet magyarázza. 1. A „kihívás hipotézis” szerint a T szint a kihívást igénylő helyzetekben, illetve az azokra való felkészüléskor megnő, ami segíti a szervezet a jobb teljesítményt elérésében (ARCHER, 2006; WINGFIELD, HEGNER, Jr és BALL, 1990). 2. A bio-szociális státusz elmélet szerint az emelkedett T szint egy versengő helyzet megnyerése után felkészíti a szervezetet a további kihívásokra, így a státusz megőrzésére, míg a csökkent $T$ szint vesztés esetén csökkenti a versengési kedvet a további státuszvesztés vagy sérülés elkerülése érdekében (MAZUR és BOOTH, 1998; MAZUR, 1985).

Mindezek ellenére a versengő helyzetben mutatott $T$ választ nem sikerült konzisztensen kimutatni minden kutatásban (például SALVADOR, SUAY, GONZÁlezBono és Serrano, 2003; SChultheiss és Rohde, 2002). EdWARds (2006) szerint a versengésre adott $\mathrm{T}$ válasz nagyban függhet pszichológiai vagy környezeti tényezőktől. Többek között olyan pszichológiai tényezők merültek fel mediátorként (vagy moderátorként), mint a hangulat (MCCAUL és mtsai, 1992; SALVADOR és COSTA, 2009), a versengés kimenetelének belső megítélése (GONZALEZ-BONO, SAlvador, Ricarte, SERrano és ARnedo, 2000), a hatalmi motiváció (SCHUltHEISS és ROHDE, 2002), vagy a győzelem szubjektív fontossága (COSTA és SALVADOR, 2012). A környezeti tényezők között a territorialitás (NEAVE és WOLFSON, 2003), az ellenfél hozzáállása (VAN DER MEIJ és mtsai, 2010), és a jutalmazás (MCCAUL és mtsai, 1992) merült fel mediátorként. Ez utóbbi különösen fontos lehet, mivel a valós életben a versengés gyakran jár pénzjutalommal vagy egyéb ösztönzővel, amelyek részben meghatározhatják a versengés intenzitását (MCCAUl és mtsai, 1992). Továbbá a jutalmak gyakran státuszváltozással is járnak (például előléptetés, díjak, nyeremények), és a T-t vizsgálatok összefüggésbe hoz- 
ták a státusszal (lásd EISENEgGer, Haushofer és FeHr, 2011). Mindezek tükrében plauzibilis feltételezés, hogy a jutalom mediátora lehet a versengésre adott $T$ válasznak.

Napjainkig csak egy kísérlet készült a jutalom manipulációjával, ahol a T változásait is mérték versengő helyzetben. Ebben a kutatásban a résztvevőknek egy pénzfeldobáson alapuló játékban kellett részt venniük, ahol nyerhettek vagy veszíthettek (MCCAUl és mtsai, 1992 második kísérlet). A résztvevők egyik csoportjának azt mondták, hogy pénzért játszik, a másiknak nem említették a jutalmat. Habár a résztvevők tisztában voltak azzal, hogy nem ők befolyásolják a versengés kimenetelét - hiszen az a véletlenen múlt -, a játék után azok, akik pénzt nyertek, magasabb T szintet mutattak, mint a vesztesek. A másik csoport tagjai - akiknek nem mondták, hogy pénzért játszanak - nem mutattak szignifikáns T választ. Ez alapján úgy tünik, hogy a jutalom moderálhatja a versengésre adott $T$ választ. Mindazonáltal a fent említett kutatásban szereplő résztvevők nem a saját erőfeszítéseiknek köszönhették a versengés eredményét. Ez a körülmény ritkán valósul meg az életben megjelenő versengő helyzetekben, ami a tanulmány általánosíthatóságát korlátozza.

Az utóbbi időben több kutatás foglalkozott a T reakció és személyiség kapcsolatával. Ezek a tanulmányok arra jutottak, hogy a személyiségvonások - amelyek a versengéshez kapcsolódó attitűdöket meghatározzák - hatással vannak a T változására győzelem vagy vesztés esetén. Például a hatalmi motiváció és T kapcsolatát több tanulmányban vizsgálták (lásd SCHULTHEISS és ROHDE, 2002). Habár a kutatások találtak összefüggést, ezek az eredmények nem teljesen konzisztensek, emiatt célravezető lehet magukat a versengési attitűdöket vizsgálni a T-vel összefüggésben.

A kardiovaszkuláris rendszer szintén érzékenyen reagál a versengésből fakadó kihívásra (HARRISON, DENNING és EASTON, 2001). Továbbá a jutalom moderálja a szívritmus változásait versengő helyzetben. Például egy tanulmányban a résztvevőket véletlenszerűen sorolták be csoportokba aszerint, hogy mekkora pénzjutalmat kaptak győzelem esetén egy szerencsejátékban (lóverseny) (WULFERT, FRANCO, WILLIAMS, ROLAND és MAXSON, 2008). A verseny alatt erős pozitív korreláció mutatkozott az előrevetített jutalom és a szívritmus között. Ezt az összefüggést olyan helyzetben is kimutatták, ahol szerencse helyett a résztvevők erőfeszítésein múlt a versengés eredménye (RICHTER és GENDOLLA, 2007, 2009). Ezek az eredmények azt sugallják, hogy a jutalom nagysága moderálhatja a szívritmust egy erőfeszítés alapú versenyben. Összességében elmondható, hogy kevés eredmény létezik a jutalmazás T-ra kifejtett hatásairól versengő helyzetekben. Egy szemtől-szembeni versenyhelyzet, ami erőfeszítést és készségeket kíván szerencse helyett, nagyban növelheti a korábbi eredmények általánosíthatóságát a való életre. Továbbá a versengő teljesítmény objektív mérése tisztázhatná a T és teljesítmény között lévő gyakran feltételezett kapcsolatot (ARCHER, 2006; MAZUR, 1985; WINGFIELD és mtsai, 1990). Érdekes módon ezt a témát eddig kevés kutatás érintette, annak ellenére, hogy a T és teljesítmény reciprok kapcsolata mindkét fent tárgyalt elméletnek meghatározó részét képezi (GLADUE, BOECHLER és MCCAUL, 1989; MazUr és LAMB, 1980). 
Hogy a korábbiakban bemutatott kérdéseket megválaszoljuk, a jelen kutatásban negyven fiatal felnőtt férfit vizsgáltunk egy harminc perces videojátékverseny közben, amely során a résztvevők pénzt nyerhettek. A versengő párosokat két csoportra osztottuk a jutalmazás típusától függően: az „egyenlőtlen jutalom” feltételben a győztes több pénzt kapott, mint a vesztes, míg az „egyenlő jutalom" feltételben mindkét fél azonos mértékủ jutalmat kapott. A T szintjét nyálból állapítottuk meg a verseny előtt és után, valamint a versengés során folyamatosan rögzítettük a szívritmust. A versenyzés előtt, közben és után többször felmértük a versenyzők hangulatát, hogy meg tudjuk figyelni a versengéssel járó hangulatváltozásokat. Predikcióink szerint a fiziológiai arousal és T szint is megemelkedik a versengés hatására, és ez a növekedés jelentősebb lesz az „egyenlőtlen jutalom” csoportban az „egyenlő jutalom” csoporthoz képest. Továbbá feltételeztük, hogy a versengő teljesítmény összefüggést mutat a $\mathrm{T}$ szinttel, azaz a magasabb $\mathrm{T}$ szint magasabb pontszámmal és nagyobb arányú győzelemmel jár. A korábbi eredmények ellentmondásosságának tükrében nem voltak szigorú elvárásaink a versengés kimenetelének (győzelem vagy vesztés) a T szintre gyakorolt hatásával kapcsolatban.

\section{MÓDSZER}

\section{Résztvevők}

A priori power elemzés alapján1 negyven fiatal, egészséges, nemdohányzó férfi vett részt a vizsgálatban. A résztvevők életkora 18 és 28 év között volt (átlag életkor $=21,7 \pm 2,3$ év; átlag BMI $=23,0 \pm 3,5 \mathrm{~kg} / \mathrm{m}^{2}$ ). Minden résztvevőnek volt korábbi tapasztalata belső nézetes lövöldözős (FPS) videojátékkal. A résztvevők a csoportbeosztásuktól függően pénzjutalmat kaptak (lásd lentebb). A kutatást jóváhagyta az ELTE Kutatásetikai Bizottsága, és a résztvevők mind aláírtak egy informált beleegyezési nyilatkozatot.

\section{Eljárás}

A kutatás résztvevői egyetemi levelezőlistákon közzétett hirdetésekre jelentkezők közül kerültek ki. Egy rövid online kérdőív alapján választottuk ki a 18 és 30 év közötti életkorú, nemdohányzó, egészséges, videojátékokat ismerő férfi jelentkezőket. Ebben a kérdőívben rákérdeztünk arra is, hogy a jelentkező mennyire sokat játszik videojátékkal (1: soha nem próbáltam, 2: már próbáltam, 3: ritkán,

\footnotetext{
${ }^{1}$ A minta méretének meghatározásához a priory power elemzést végeztünk a GPower 3.1 szoftverrel (FAUl, ERDFELDER, LANG és BUCHNER, 2007). Az elemzés paraméterei egy korábbi hasonló kutatáson alapultak (MCCAul, GLAdue és JOPPA, 1992, második kísérlet). A statisztikai powert a kevert típusú varianciaanalízis between-within interakciójára határoztuk meg (elvárt hatásméret (f) $=0,25$ (közepes); alfa $=0,05 ; 1$-béta $=0,80$; between subject csoportok száma $=4$; mérések száma $=2$ (T minták száma résztvevőnként); mérések közötti korreláció $=0,6$ ).
} 
4: gyakran, 5: nagyon gyakran), és arra, hogy mennyire tartja magát jó játékosnak (1: nagyon rossz, ..., 5: nagyon jó). A kiválasztott jelentkezőket párosokba osztottuk aszerint, hogy melyik időpontokban értek rá, és telefonon egyeztettünk a vizsgálat időpontjáról. A párosokat véletlenszerűen „egyenlő jutalom” vagy „egyenlőtlen jutalom” csoportokba osztottuk. Pontosan egy nappal a megbeszélt időpont előtt a résztvevők kaptak egy e-mailt, ami a részvétel feltételeiről, a vizsgálati feladatról (játékkal kell játszani egymás ellen) és a vizsgálat jutalmazásáról tartalmazott információkat. Az egyenlőtlen jutalom csoportban lévők azt az információt kapták, hogy a teljesítményüktől függően kapnak jutalmat (a győztes 3000 , a vesztes 1000 forintot), míg az egyenlő jutalom csoportban lévők azt az információt kapták, hogy a teljesítményüktől függetlenül kapnak jutalmat (15001500 forintot). Ezt az információt a vizsgálat elején a kísérletvezető is megismételte. A tájékoztató e-mailben a részvevők - csoportbeosztástól függetlenül - a részvétel feltételeiről is kaptak információkat. Ebben megkértük őket, hogy a kutatás napján tartózkodjanak a dohányzástól, alkoholos és koffeines italoktól, ne végezzenek kimerítő testmozgást, a kutatást megelőző két és fél órában ne egyenek, és a kutatás előtti egy órában ne mossanak fogat (a fogínyvérzés elkerülése miatt, ami a nyáltesztoszteron szintjét befolyásolhatja).

A méréseket egy férfi kutatásvezető irányította. A vizsgálatok körülbelül egy órát vettek igénybe, és mindegyik 12 és 17 óra között került lebonyolításra, a T cirkadián ritmusából fakadó hatásának minimalizálása érdekében (DABBS, DE LA RUE és Williams, 1990). A résztvevők külön érkeztek, és kb. 15 percet pihentek, mielőtt elkezdődött a vizsgálat. Ennek során a résztvevők megismerték a párjukat, ám hosszabb beszélgetésre nem volt lehetőségük. Ezután a kísérletvezető egy légkondicionált laborhelyiségbe vezette a párokat. Rövid tájékoztató után a kutatásvezető felhelyezte a szívritmusmérő eszközöket, és ellenőrizte azok működését. Majd elmagyarázta a résztvevőknek a feladatot és bemutatta a játékot, amiben a résztvevőknek versengenie kellett egymással. A résztvevők kipróbálhatták a játék irányítását, illetve megismerték a hangulatfelmérő kérdőívet, amit többször ki kellett tölteniük a mérés során (a mérőeszközök, tesztek és a versengő játék részletes leírását lásd lentebb).

Mindezek után a kísérletvezető rögzítette a szívritmus baseline-t, kitöltette az első hangulati kérdőívet, majd begyưjtötte az első nyálmintát. Ezt követően a résztvevőknek egy versengő videojátékot kellett játszaniuk egymással 30 percen keresztül, hat darab ötperces szakaszra osztva. A szakaszok alatt folyamatosan rögzítésre került a szívverések között eltelt idő (inter-beat interval). Az egyes szakaszok között és a játék végén a résztvevők kitöltötték a hangulati kérdőívet. A kutatásvezető folyamatosan informálta a játékosokat a pontjakról, és hogy ki áll nyerésre. A hatodik szakasz végén a kutatásvezető kihirdette a győztest. Ezután levette a második nyálmintát, rögzítette a nyugalmi szívritmust, kitöltette az utolsó hangulati kérdőívet, valamint kitöltetett egy versengési attitűdökkel kapcsolatos kérdőívet. 


\section{Versengö feladat}

A résztvevők egy népszerủ belső nézetű lövöldözős videojátékkal játszottak (Call of Duty: Modern Warfare 2; Activision, Santa Monica, USA) versengő, egymás elleni játékmódban. A játékosok feladata az volt, hogy megtalálják és megsemmisítsék egymás avatárját; akinek ez sikerült, egy pontot kapott. A megsemmisített avatár rögtön visszakerült a játékba a játéktér egy másik pontján mindaddig, amíg tartott az adott játékszakasz. A játékosok harminc percig, hat darab ötperces játékszakaszon keresztül versengtek egymással. Az a játékos, akinek a hatodik játékszakasz végén több pontja volt, mint ellenfelének, megnyerte a játékot. A játékban végeredményből kiszámításra került a végső pontkülönbség (győztes pontjai vesztes pontjai). Az eseménytelen játékmenet elkerülése érdekében a játékosok folyamatosan látták egymás helyzetét egy radaron.

A játékot egy XBOX 360 játékkonzol (Microsoft; Redmond, USA) futtatta, a játékképernyőt vertikális osztott módban egy projektor vetítette ki a falra (XGA VPL-CX10; Sony, Tokyo, Japan), míg a hangokat aktív hangszórók biztosították (SP-S350, Genius; Taipei, Taiwan). A résztvevők a játékot vezeték nélküli XBOX 360 kontrollerekkel irányították (Microsoft; Redmond, USA).

\section{Hangulati kérdöív}

A résztvevőknek egy 9×9-es érzelmi rácson kellett megítélniük aktuális hangulatukat. Az érzelmi rácson a függőleges tengelyen jelezték azt, hogy mennyire érzik magukat ébernek ( -4 : nagyon álmos, +4 nagyon éber), a vízszintes tengelyen azt, hogy mennyire érzik magukat kellemesen $(-4$ : nagyon kellemetlen, +4 nagyon kellemes) (Russell, WeIss és MENDELSOHN, 1989).

\section{Versengési attitüd kérdörv}

A versengési attitűdöket a hiperversengés és az önfejlesztő versengés skálák segítségével mértük (RYCKMAN, HAMMER, KACZOR és GOLD, 1990, 1996). A hiperversengés azt a versengő attitűdöt jelenti, amikor az egyén kizárólag a győzelmet tartja szem előtt bármi áron, valamint minden lehetőséget kihasznál a versenyzésre az élet bármely területén. Az önfejlesztô versengő személy ezzel szemben a versengést saját fejlesztésére használja fel, és ezért a versengés folyamatát sokkal fontosabbnak tartja, mint a tényleges győzelmet. Mindkét skála versengéssel kapcsolatos állításokat tartalmaz, amelyekkel a kitöltők ötfokú Likert-skálán fejezhetik ki egyetértésüket (1: nagyon nem ért egyet, 2: inkább nem ért egyet, 3: egyet is ért meg nem is, 4: inkább egyetért, 5: nagyon egyetért). A hiperversengés skála 26, az önfejlesztő versengés skála 15 itemet tartalmaz. Mindkét skálát a korábban validált magyar változatban használtuk (FÜLÖP, SzŐLLŐS, SZŐNYI és TELCS, 1999), és a skálák elfogadható belső reliabilitást mutattak ( $\alpha=0,82$ mindkét skálán). 


\section{Szíuritmus mérése}

A szívritmus és szívritmus-variabilitás mérésére Actiheart eszközöket használtunk (Camntech, Cambridge, UK), amelyeket öntapadós elektródákkal rögzítettünk a résztvevők mellkasára (Fiab, Vicchio, Olaszország). Az egyik elektródát a szegycsont csúcsára, a másikat a mellbimbó alá rögzítettük az eszköz leírásának megfelelően. Az eszköz megbízhatóságát és eredményeinek validitását korábbi tanulmányok igazolták (BRAGE, BRAGE, FrANKS, EKELUND és WAREHAM, 2005). Az eszköz által rögzített szívverések között eltelt idő (IBI) alapján kiszámításra került a játék előtti (baseline), játékszakaszok alatti és játék utáni (nyugalmi) szívritmus, valamint szívritmus-variabilitás RMSSD komponense, ami a vegetatív idegrendszer paraszimpatikus aktivitásának egyik megbízható és gyakran alkalmazott mutatója (MALIK és mtsai, 1996).

\section{Tesztoszteronmérés és elemzés}

A nyálmintákat polipropilén alapú salivette nyálmintavevőkkel (Sarstedt; Nümbrecht, Németország) gyüjtöttük, öt perccel a játék előtt, illetve öt perccel a hatodik játékszakasz után. Két résztvevő túl kevés nyálmintát adott, ezért 38 résztvevő nyálminta adatai voltak alkalmasak az elemzésre. A nyálat centrifugálás után -20 ${ }^{\circ} \mathrm{C}$-on tároltuk az elemzésig. A nyáltesztoszteron szintjét duplikált eljárásban mértük kereskedelmi forgalomban kapható EIA csomag segítségével (1-2402, Salimetrics, State Collage, USA) a gyártó előírásainak megfelelően. Az elemzési minta érzékenysége $1 \mathrm{pg} / \mathrm{ml}$. A mintán belüli variációs együttható (CV\%) az alacsony $(18,2 \mathrm{pg} / \mathrm{ml})$ és magas $(188,83 \mathrm{pg} / \mathrm{ml})$ T koncentrációjú mintákban 6,7\% és $2,5 \%$ volt, sorrendben. A minták közötti variációs együttható $15,9 \%$ volt az alacsony, és 2,6\% volt a magas $\mathrm{T}$ koncentráció esetén. A baseline és játék utáni T szint normális eloszlást mutatott a Shapiro-Wilks-tesztek alapján.

\section{Adatredukció és statisztikai elemzés}

Az előzetes statisztikai elemzéshez $2 \times 2$ varianciaanalízist használtunk, amelyben a jutalmazási csoport (egyenlő vagy egyenlőtlen jutalom) $\times$ Eredmény (győztes vagy vesztes) voltak a between-subject változók. Kevert típusú, $2 \times 2 \times 8$ varianciaanalíziseket használtunk az arousal, kellemesség, szívritmus, szívritmus-variabilitás elemzéséhez (Jutalmazási csoport $\times$ Eredmény $\times$ Szakasz), ahol a jutalmazási csoport és az eredmény between-subject, míg a szakasz within-subject változók voltak. A szfericitás vizsgálatát Mauchly-teszttel végeztük, és a szükséges esetekben HuynFeldt-korrekciót alkalmaztunk. Ezekben az esetekben a szövegben közöljük a vonatkozó epszilon $(\varepsilon)$ értéket és a korrigálatlan szabadságfokot $(\mathrm{df})$, a korrigált szignifikanciaértékkel (p) együtt (KESELMAN, 1998). A szignifikáns hatásokat különálló egyutas varianciaanalízisekkel, illetve t-próbákkal (Sidak-korrekció) vizsgáltuk tovább. A T szinteket kevert szempontú $2 \times 2 \times 2$ kovarianciaanalízissel ele- 
meztük, ahol a jutalmazási csoport és az eredmény between-subject, míg a szakasz within-subject változók voltak, és a napszak a kovariáns. Outlier-nek a 3,0 szóráson kívül eső értékeket tekintettük, amelyeket eltávolítottuk ( $\mathrm{N}=2 \mathrm{az}$ RMSSD adatokban). Az adatok normalitását Saphiro-Wilk-teszttel ellenőriztük. A nem normális eloszlású változókat nem-parametrikus statisztikai módszerekkel elemeztük (Mann-Whitney U teszt, Spearman rang-korreláció). Az elemzéseket IBM SPSS Statistics 20 programmal végeztük.

\section{EREDMÉNYEK}

\section{Az alcsoportok elözetes elemzése}

A leíró statisztikákat a vizsgálati csoportok jellemzőiről az 1. táblázat tartalmazza. A csoportok átlagos életkorában ( $\mathrm{U}<223,5 ; p>0,517)$, testtömeg-indexében ( $\mathrm{U}$ $<171,5 ; p>0,399$ ) és játéktudásában nem volt szignifikáns különbség ( $\mathrm{U}<$ $256,5 ; p>0,507)$. A résztvevők az egyenlő jutalom csoportban átlagosan többet játszottak videojátékokkal $(\mathrm{U}=285,5, p=0,014)$. A hiperversengés skálán elért pontszámban nem volt különbség az alcsoportok között ( $\mathrm{F}<0,89$; $\mathrm{p}>0,350)$, míg az önfejlesztő versengésben az egyenlő jutalom csoport átlaga kis mértékben magasabb volt, mint az egyenlőtlen csoport átlaga $\left(\mathrm{F}=7,19 ; p=0,011 ; \eta_{p}{ }^{2}=\right.$ $0,17)$.

A versengő teljesítményt tekintve a győztesek végső pontszáma természetesen nagyobb volt, mint a vesztesek pontszáma ( $\mathrm{U}=316,0 ; p=0,002)$. A pontkülönbség a győztesek és vesztesek között magasabb volt az egyenlőtlen jutalom csoportban, azonban ez a különbség csak tendenciaszintű volt $(\mathrm{U}=26,0 ; p=0,069)$.

1. táblázat. Az alcsoportok átlagai (szórásai) a résztvevők tulajdonságai és a versengő teljesítmény szerint

\begin{tabular}{|c|c|c|c|c|}
\hline & \multicolumn{2}{|c|}{ Egyenlőtlen jutalom } & \multicolumn{2}{|c|}{ Egyenlő jutalom } \\
\hline & Győztes & Vesztes & Győztes & Vesztes \\
\hline \multicolumn{5}{|l|}{ Résztvevők tulajdonságai } \\
\hline Életkor (év) & $21,4 \quad(2,5)$ & $21,8 \quad(2,7)$ & $21,4 \quad(2,2)$ & $22,0 \quad(1,9)$ \\
\hline BMI $\left(\mathrm{kg} / \mathrm{m}^{2}\right)$ & $23,6 \quad(3,3)$ & $23,6 \quad(3,7)$ & $21,4 \quad(3,8)$ & $23,4 \quad(3,0)$ \\
\hline Játéktudás & $3,6 \quad(0,8)$ & $3,6 \quad(1,0)$ & $4,0 \quad(0,8)$ & $4,1 \quad(1,0)$ \\
\hline Játék gyakoriság & $3,2 \quad(0,6)$ & $3,2 \quad(0,8)$ & $4,0 \quad(1,1)$ & $3,9 \quad(1,1)$ \\
\hline Hiperversengés & $3,0 \quad(0,4)$ & $2,6 \quad(0,6)$ & $2,9 \quad(0,5)$ & $3,1 \quad(0,5)$ \\
\hline Önfejlesztő versengés & $3,4 \quad(0,6)$ & $3,7 \quad(0,4)$ & $4,0 \quad(0,4)$ & $3,9 \quad(0,3)$ \\
\hline \multicolumn{5}{|l|}{ Versengő teljesítmény } \\
\hline Végső pontszám & $43,2(18,0)$ & $22,4(13,4)$ & $41,7(16,2)$ & $29,9 \quad(7,7)$ \\
\hline Pontkülönbség & \multicolumn{2}{|c|}{$21,1(17,8)$} & \multicolumn{2}{|c|}{$11,5(14,7)$} \\
\hline
\end{tabular}

Megjegyzés: minden alcsoport létszáma 10 fő 


\section{Hangulat kérdöívek}

A versengés előtti szubjektív arousal magasabb volt az egyenlőtlen jutalom csoportban, mint az egyenlő jutalom csoportban $(t(38)=2,59 ; p=0,013)$. Az arousal szintje megnövekedett a verseny alatt, majd lecsökkent utána mindkét csoportban $\left(F(7 ; 252)=23,80 ; p<0,001 ; \varepsilon=0,95, \eta_{p}^{2}=0,40 ; 1 a\right.$ ábra $)$. A versengés kimenetele nem volt hatással az arousalre $(F(7 ; 252)=0,88 ; p=0,521)$.

A kellemességgel kapcsolatban a Kimenetel $\times$ Szakasz interakció megmutatta, hogy a győztesek pozitívabb hangulatba kerültek a játék végén a vesztesekhez képest $\left(F(7 ; 252)=2,94 ; p=0,006 ; \varepsilon=0,86 ; \eta_{p}^{2}=0,09\right)$. A poszt-hoc teszt szerint ez a különbség a győztes kihirdetésekor volt csak szignifikáns $(t(38)=-4,17$; $p<$ $0,001 ; 1 b$ ábra $)$. A kellemességet nem befolyásolta a jutalmazási csoport $(F(7 ; 252)$ $=1,16 ; p=0,328)$.

\section{Szívritmus és szíuritmus-variabilitás}

A szívritmus átlagosan 13\%-kal nőtt a baseline-hoz képest a verseny alatt, majd utána visszatért az eredeti értékre $\left(F(7 ; 252)=36,85 ; p<0,001 ; \varepsilon=0,49 ; \eta_{p}{ }^{2}=\right.$ $0,51)$. Habár a résztvevőknek az egyenlőtlen jutalmazási csoportban mindegyik szakaszban magasabb volt a szívritmusa, mint az egyenlő jutalom csoportba tartozóké, ez a különbség statisztikailag nem volt szignifikáns $(F(7 ; 252)=1,91 ; p=$ $0,124)$. Ezen felül a versengés kimenetele (győzelem vagy vesztés) sem függött össze a szívritmussal $(F(7 ; 252)=0,18 ; p=0,930)$.

A szívritmus-variabilitás (RMSSD) 21\%-kos csökkenést mutatott, jelezve, hogy a paraszimpatikus aktivitás csökkent a verseny alatt a baseline-hoz és a játék utáni értékhez képest $\left(F(7 ; 238)=9,28 ; p<0,001 ; \varepsilon=0,56 ; \eta_{p}^{2}=0,21\right)$. A jutalmazási csoport $(F(7 ; 238)=1,83 ; p=0,129)$ és a versengés kimenetele $(F(7 ; 238)=$ $0,67 ; p=0,609)$ nem befolyásolták az RMSSD-t.

\section{Tesztoszteron}

Az előzetes hipotézissel ellentétben a $\mathrm{T}$ szintje nem változott a versengés hatására $\left(F(1 ; 34)=1,75 ; p=0,194 ; \eta_{p}^{2}=0,05\right)$, valamint nem volt kimutatható hatása sem a jutalmi feltételnek $\left(F(1 ; 34)=1,80 ; p=0,188 ; \eta_{p}^{2}=0,05\right)$, sem a versengés kimenetelének $\left(F(1 ; 34)=0,14 ; p=0,716 ; \eta_{p}^{2}=0,00\right)$. 


\section{a) Szubjektív arousal}

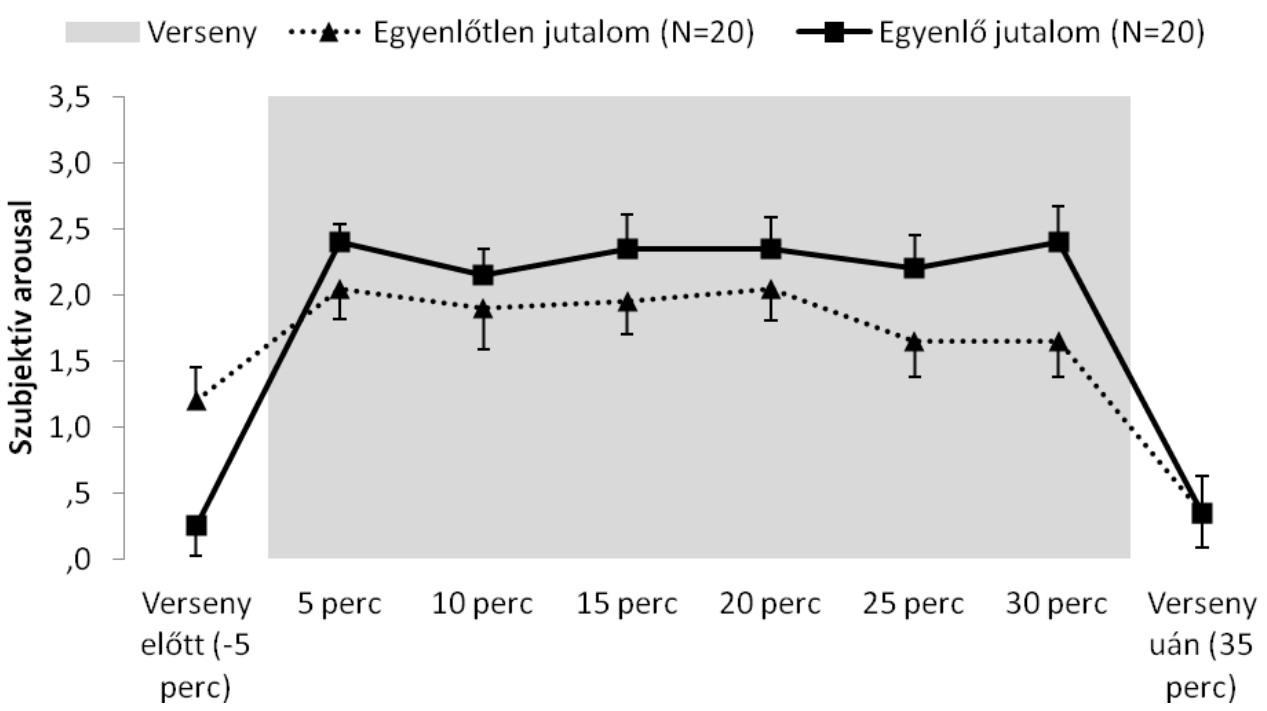

\section{b) Kellemesség}
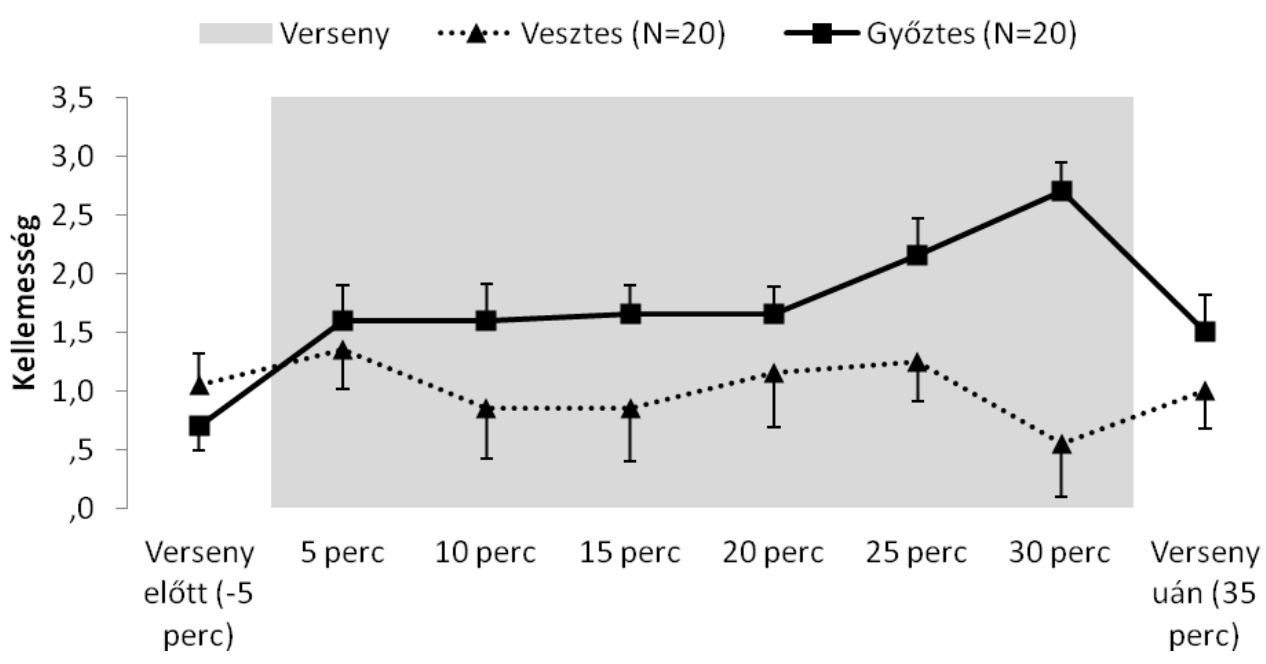

1. ábra. A szubjektív arousal (a) és kellemesség (b) átlaga a verseny előtt, közben és után a különböző jutalmazási csoportokban (a), illetve versengési kimeneteleknél (b). A hibasávok a standard hibát jelzik. 
a) Szívritmus

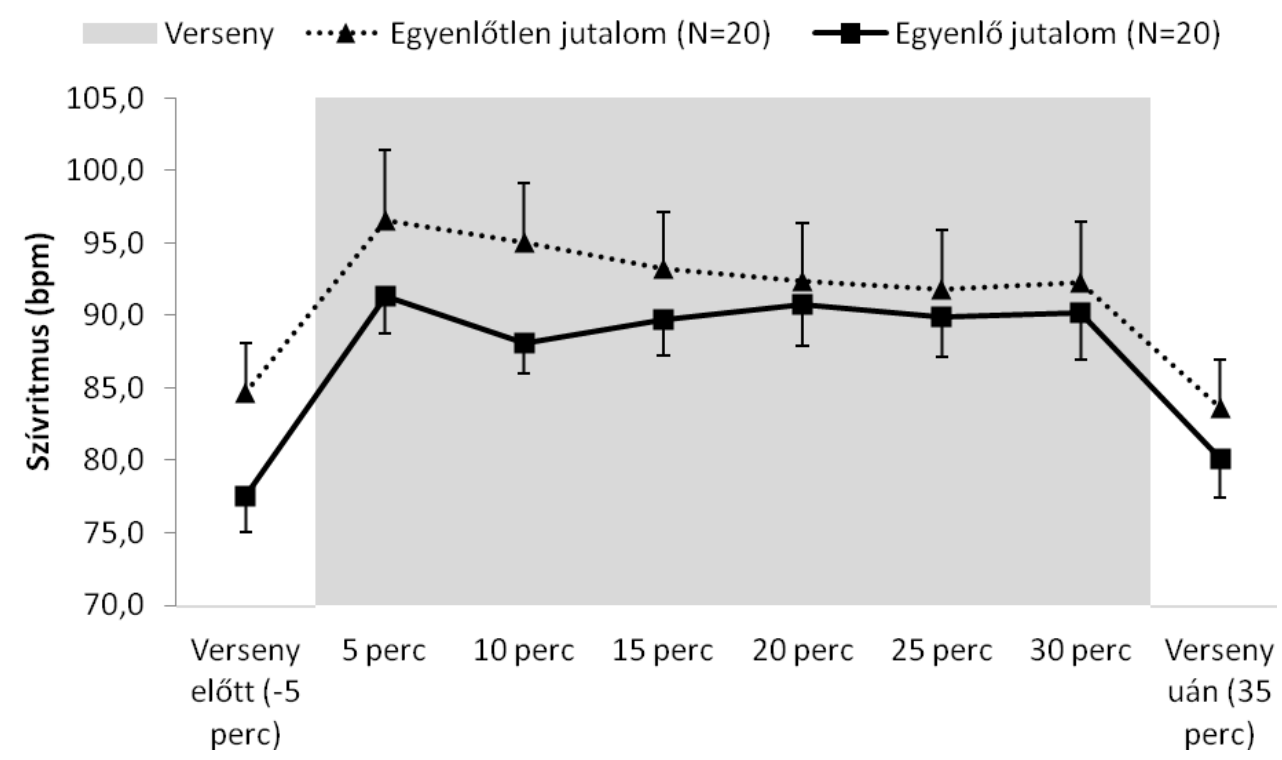

b) Szívritmus variabilitás (RMSSD)

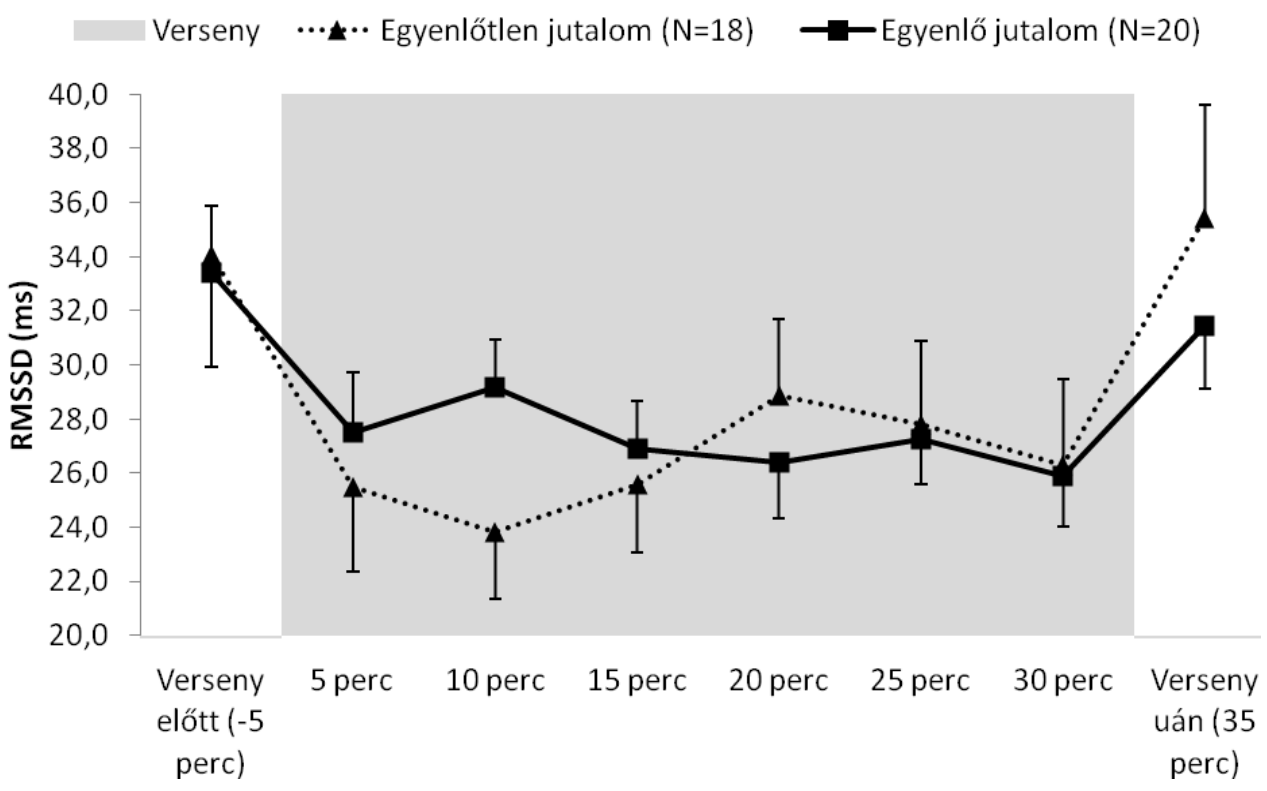

2. ábra. A szívritmus (a) és szívritmus-variabilitás (b) átlaga a verseny előtt, közben és után a különböző jutalmazási csoportokban. A hibasávok a standard hibát jelzik. 
2. táblázat. A verseny előtti és utáni tesztoszteronszint átlagai (szórásai) a jutalom és versengési kimenetel szerinti alcsoportokban

\begin{tabular}{|l|c|c|c|c|}
\hline \multirow{2}{*}{} & \multicolumn{2}{|c|}{ G y ő z t e s } & \multicolumn{2}{c|}{ V e s z t e s } \\
\cline { 2 - 5 } & $\begin{array}{c}\text { Versengés } \\
\text { előtti T }\end{array}$ & $\begin{array}{c}\text { Versengés } \\
\text { utáni T }\end{array}$ & $\begin{array}{c}\text { Versengés } \\
\text { elötti T }\end{array}$ & $\begin{array}{c}\text { Versengés } \\
\text { utáni T }\end{array}$ \\
\hline Egyenlötlen jutalom $(\mathrm{N}=20)$ & $76,2(19,8)$ & $72,3(15,7)$ & $77,0(16,4)$ & $72,6(20,0)$ \\
\hline Egyenlő jutalom $(\mathrm{N}=18)$ & $71,5(27,6)$ & $65,4(28,6)$ & $61,1 \quad(16,7)$ & $65,2(19,1)$ \\
\hline
\end{tabular}

Megjegyzés: A tesztoszteronértékek mértékegysége: pg/ml.

\section{Versengő attitüdök és tesztoszteron összefüggései}

Habár a T szint átlagosan nem változott a versengés hatására, jelentős egyéni különbségek mutatkoztak a változás mértékében. Az egyéni különbségek kivizsgálásához moderátorelemzést végeztünk, ahol a T változás volt a kimeneti változó, a két versengési attitűd a prediktor, valamint a versengés kimenetele és a jutalmazási csoport a moderátorok (HAYES, 2013). A moderátorelemzés megmutatta, hogy a hiperversengő attitűd a versengés kimenetelével interakcióban határozta meg a T változást $(\mathrm{b}=-21,42 ; t=-2,67 ; p=0,012$; modell $F(5 ; 32)=2,71 ; p=$ 0,$\left.007 ; \mathbf{R}^{2}=0,30\right)$, míg a jutalmazási feltétel nem volt szignifikáns moderátor $(p=$ $0,735)$. Ez az összefüggés azt mutatja, hogy a hiperversengőbb résztvevők a vesztés hatására megnövekedett $T$ szintet, győzelem hatására csökkent $T$ szintet mutattak (lásd 3. ábra) a jutalmazási feltételtől függetlenül. Az önfejlesztő versengés és annak interakciói a jutalmazással és a versengés kimenetelével nem bizonyultak szignifikáns prediktornak (modell $F(5 ; 32)=1,00 ; p=0,436 ; \mathrm{R}^{2}=0,13$ ).

\section{A tesztoszteron összefüggései a versengő teljesítménnyel}

A 3. táblázat mutatja be a korrelációkat a versengő teljesítmény mutatói (végső pontszám, pontszámkülönbség), és a T szint (verseny előtti és utáni T, és T változás) között győzteseknél (az átló fölötti értékek) és veszteseknél (átló alatti értékek). Mivel a jutalmazási csoportok nem gyakoroltak jelentős hatást a T szintjére, ezért az egyenlő és egyenlőtlen jutalmazási csoportok korrelációi nem kerülnek bemutatásra. A győztesek versengés előtti és utáni T szintje és a végső pont, valamint pontkülönbség között szignifikáns pozitív korrekciót találtunk. Tehát a magasabb T szinttel rendelkező győztesek hajlamosabbak voltak nagyobb vereséget mérni ellenfeleikre. A vesztesek verseny előtti és verseny utáni T szintje nem függött össze teljesítményükkel, ám a végső pontszámuk szignifikánsan és pozitívan összefüggött a $T$ változásával a verseny alatt. Tehát azok a vesztesek, akik magasabb pontszámot értek el, kisebb T csökkenést (vagy nagyobb növekedést) mutattak a verseny alatt. Továbbá a vesztesek $T$ változása negatívan korrelált a pontkülönbséggel, tehát a megsemmisítőbb vereség nagyobb T csökkenéssel járt együtt. 


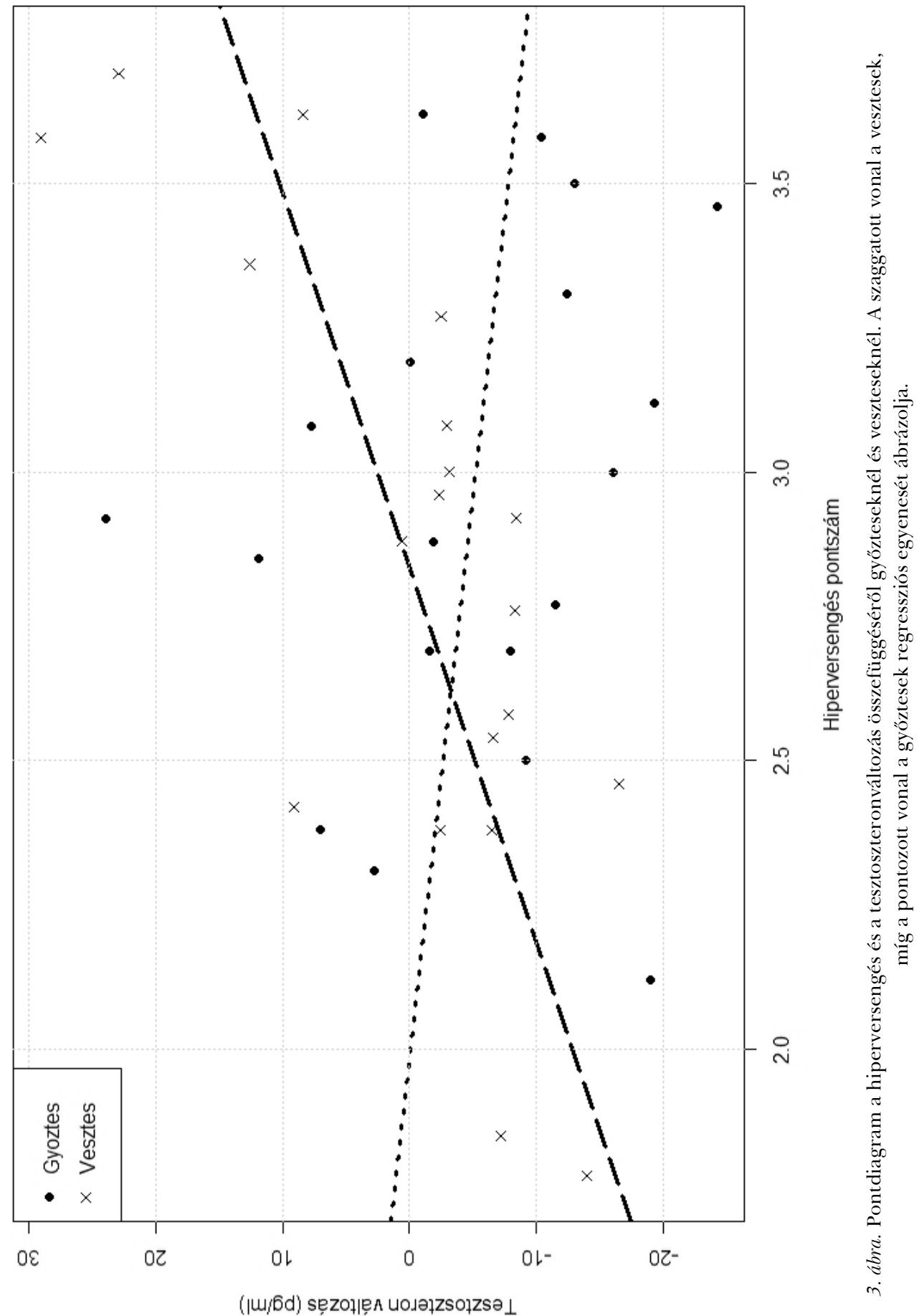


3. táblázat. A versengő teljesítmény és tesztoszteron korrelációi (Spearman-rho együtthatók)

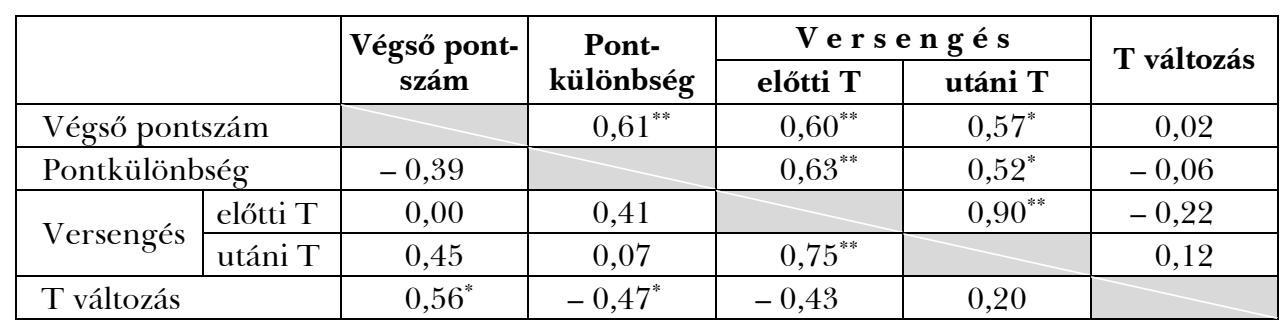

Megjegyzés: Az átló feletti értékek a győztesek $(\mathrm{N}=19)$, míg az átló alatti értékek a vesztesek $(\mathrm{N}=19)$ korrelációs együtthatóit tartalmazzák. " : $p<0.05,{ }^{* *}: p<0.01$.

\section{DISZKUSSZIÓ}

Jelen kutatás azt vizsgálta, hogy versengő kontextusban a különböző jutalmazási feltételek és versengési attitűdök meghatározzák-e a pszichofiziológiai és endokrinológiai változásokat, valamint a versengési teljesítményt. A versengés során nőtt a szubjektív arousal és a szívritmus, valamint csökkent a szívritmus-variabilitás. A győztesek a játék végén kellemesebben érezték magukat, mint a vesztesek. A jutalmazás típusa nem befolyásolta szignifikánsan a pszichofiziológiai és hangulati változásokat, továbbá az előzetes elvárással ellentétben a T szintje átlagosan nem változott a versengés alatt. Azonban a moderátorelemzés megmutatta, hogy a hiperversengőbb résztvevők a vesztés hatására megnövekedett T szintet, győzelem hatására csökkent T szintet mutattak. Továbbá a győztesek verseny előtti és utáni T szintje pozitívan korrelált a végső pontszámukkal és a pontszámkülönbséggel, valamint a vesztesek $T$ változása negatívan korrelált a pontszámkülönbséggel.

Tudomásunk szerint ez az első próbálkozás, amikor egy versengési attitűd - a hiperversengés - jelenségét a $T$ változásához sikerült kötni. A T szint és a versengő teljesítmény kapcsolatát bemutató korrelációk - habár meghatározó szerepet töltenek be mind a kihíváshipotézis, mind a bio-szociális státuszelmélet megalapozásában - eddig csak kevés empirikus alátámasztást kaptak.

\section{A versengésre adott pszichofiziológiai válasz}

Függetlenül a jutalmazástól és a kimeneteltől, a versengés alatt megnőtt a szubjektív arousal, a szívritmus, valamint csökkent a szívritmus-variabilitás a versengés előtti és utáni értékekhez képest. Ezzel a jelen kutatás azokat a korábbi eredményeket ismételte meg, amelyek szerint a kihívást jelentő versengés növeli a fiziológiai és szubjektív arousalt, a szívritmust, és csökkenti a paraszimpatikus aktivitást (COSTA és SALVADOR, 2012).

A T szintje átlagosan nem növekedett a versengés hatására. Habár ez nincs összhangban a kihívás hipotézissel, számos egyéb kutatás hasonló eredményt mu- 
tatott (például Mazur, Susman és Edelbrock, 1997; SAlvador és mtsai, 2003; SchulTheiss és ROHDE, 2002). Elképzelhető, hogy a T szintje már a baseline nyálminta begyűjtése előtt emelkedett volt, megnehezítve a további növekedés észlelését (MAZUR és mtsai, 1997; SUAY és mtsai, 1999). Az is lehetséges, hogy a T változás hiánya a fizikai kifáradás hiányának tulajdonítható. ARCHER (2006) metaanalízisében arra jutott, hogy azok a versenyhelyzetek, amelyek fizikai erőfeszítéssel járnak, nagyobb hatást gyakorolnak a T szintjére, mint a testmozgással nem járó versenyhelyzetek. Ezzel összefüggésben elképzelhető, hogy a fizikai kifáradás moderálja a versengés és T változás közötti összefüggést (EDWARDS, 2006).

\section{A jutalmazás hatása}

A versengés előtti szubjektív arousal magasabb volt az egyenlőtlen jutalmazási csoportban, mint az egyenlő jutalmazási csoportban. Ez arra utal, hogy a résztvevők tudatában voltak a csoportok közötti különbségnek, és a nagyobb kihívást, illetve jutalmat ígérő helyzet nagyobb izgatottságot váltott ki a versenyt megelőzően. Ennek ellenére a verseny közben ez a különbség nem mutatkozott tisztán sem a szubjektív arousalben, sem a pszichofiziológiai változókban. Az egyetlen korábbi tanulmány, ami a T és jutalmazás kapcsolatát vizsgálta versenyhelyzetben, azt találta, hogy a nagyobb jutalom nagyobb T változásokkal jár (MCCAUL és mtsai, 1992). A mi eredményeink nem támasztották alá ezt a megfigyelést.

A T válaszokkal ellentétben a versenyhelyzetben jelentkező kardiovaszkuláris változásokat számos kutatás vizsgálta a jutalmazással kapcsolatban. Ezek a vizsgálatok azt mutatták, hogy a nagyobb nyeremény lehetősége nagyobb kihívást eredményez, amire a szervezet megemelkedett szívritmussal, és csökkent paraszimpatikus aktivitással válaszol (RICHTER és GENDOLLA, 2007, 2009; WULFERT és mtsai, 2008). A jelen vizsgálat nem tudta ezeket az eredményeket igazolni. Úgy gondoljuk, hogy a jutalmazás hatása azért nem mutatkozott meg a T szint - és a fiziológiai változók - változásában, mert a jutalom manipulációja nem volt megfelelő. Egyrészt a jutalom különbség mértéke talán túl csekély volt az egyenlőtlenül jutalmazott helyzetben. Másrészt nemcsak a győztes, hanem a vesztes is kapott egy alacsonyabb jutalmat. Harmadrészt maga a játék is lehetett jutalmazó értékű, a pénzjutalomtól függetlenül, ami összezavarhatta a jutalommanipuláció hatását. Egy további lehetőség, hogy az a priori elemzés ellenére alábecsültük a szükséges minta nagyságát, ezért a tanulmány statisztikai ereje nem volt elégséges. Ezekből kiindulva a jövőbeli tanulmányoknak érdemes lenne élesebb különbséget kialakítani győztes és vesztes között, ha a jutalom T-ra gyakorolt hatását szeretnék vizsgálni.

\section{A versengés kimenetele}

A győztesek jobb hangulatról számoltak be a verseny végén, mint a vesztesek. Ennek ellenére a versengés utáni T szint nem különbözött a győztesek és veszte- 
sek között. A győztesek és vesztesek T szintje közötti T különbséget számos egyéb tanulmány sem tudta kimutatni (például MAZUR és mtsai, 1997; VAN DER MEIJ és mtsai, 2010). A versengés kimenetele mindazonáltal jelentősnek bizonyult, ám nem önmagában, hanem a versengési attitűddel (hiperversengéssel) összefüggésben.

\section{$A$ versengö attitüdök szerepe a T válaszban}

A magasabb hiperversengés pontszámmal jellemezhető résztvevők a vesztés hatására megnövekedett T szintet, győzelem hatására csökkent T szintet mutattak. Ez az eredmény látszólag ellentmond a bio-szociális státuszelméletnek, amely a győzelem esetén T növekedést, vesztés esetén T csökkenést prognosztizál (MAZUR és BOOTH, 1998; MAZUR, 1985). Újabb eredmények azt mutatják, hogy a versengés kimenetelére adott $\mathrm{T}$ reakció összefüggésben lehet a státusz visszaszerzésére irányuló törekvéssel. MEHTA és JOSEPHS (2006) azt találták, hogy a T növekedés egy verseny elveszítése után összefüggésbe hozható a visszavágó utáni vággyal. Következtetéseik szerint azok a vesztesek, akik növekedő T szintet mutatnak, egy viszszavágóval visszanyerhetik státuszukat, míg azok a vesztesek, akik csökkenő T szinttel reagálnak, visszavonulnak a versengéstől a további státuszcsökkenés elkerülése érdekében.

Egy friss tanulmány felveti, hogy instabil hierarchiaviszonyok között a vesztesek és győztesek $\mathrm{T}$ reakciója pont a fordítottja lehet annak, amit a bio-szociális státuszelmélet meghatároz (ZILIOLI, MEHTA és WATSON, 2014). A „státusz instabilitás hipotézis" szerint egy instabil hierarchiában az alacsonyabb státusz (vesztés) T növekedést valószínűsít, míg a magasabb státusz (győzelem) inkább T csökkenést (ZILIOLI és mtsai, 2014). Ebben az elméletben leginkább a T kockázatvállaló viselkedésre kifejtett hatása hangsúlyozódik ki, azaz hogy a növekedett T szintű versenyző inkább hajlamosabb felvállalni egy újabb versenyt, hogy javítsa a pozícióját, míg egy csökkent T szintű versenyző inkább elkerüli azt, hogy megtartsa pozícióját (MEHTA és Josephs, 2006).

A hiperversengők esetében a státuszszerzés vágya hangsúlyosabban jelentkezik, ezért jobban megmutatkozhatnak a státusz instabilitás hipotézis által elővetített T változások is (RYCKMAN, THORNTON és BUTLER, 1994). A hiperversengő személyekre jellemző továbbá a státuszhierarchia figyelmen kívül hagyása (azaz a vesztés elfogadásának nehézsége), ami tovább valószínűsíti a fent említett $T$ változásokat (RYCKMAN és mtsai, 1994). Ennek megfelelően a jelen kutatás a hiperversengéssel jobban jellemezhető veszteseknél T növekedést, míg a nyerteseknél T csökkenést talált. Egy instabil hierarchiában - mint például a jelen kutatásban, ahol a viszonylag rövid ideig tartó versengés nem vezet stabil hierarchiához - a győztes akkor jár jól, ha nem megy bele egy újabb versenybe, hiszen abban könynyen alulmaradhat, elveszítve a megszerzett magasabb pozícióját. Ezt a döntést elősegítheti a versengési/kockázatvállalási kedv csökkenése, ami a T csökkenéssel jár (STANTON, Liening és Schultheiss, 2011). 


\section{Versengő teljesítmény és tesztoszteron}

Habár a T és státusz kapcsolatát magyarázó elméleti modellek nagy hangsúlyt fektetnek a T és a teljesítmény kapcsolatára (a T növelni hivatott a versengó teljesítményt), ehhez képest meglepően kevés kutatás támasztja alá ezt az összefüggést (GLADUE és mtsai, 1989; MAZUR és mtsai, 1992; vAN ANDERS és WATSON, 2007). Többek között ezt a hiányosságot igyekezett pótolni a jelen tanulmány azáltal, hogy egy jól számszerűsíthető mutatót használt a versengő teljesítmény mérésére (végső pontszám és a pontkülönbség). Az eredmények azt mutatták, hogy a magasabb T szintű nyertesek magasabb pontszámot értek el, illetve nagyobb mértékben növelték a pontkülönbséget a játék során. Más szóval a magas T szintű nyertesek megsemmisítőbb vereséget mértek az ellenfelükre. Továbbá a pontkülönbség a vesztesek $T$ változásával negatívan korrelált. Ezek az eredmények azon korábbi megfigyelésekkel konzisztensek, amelyek szerint a győzelem vagy vereség módja (például megsemmisítő vagy szoros) moderálhatja a versengés T-re kifejtett hatását (GLADUE és mtsai, 1989; MAZUR és LAMB, 1980). Ez az eredmény összefügg a korábban említett státusz instabilitás hipotézissel, hiszen a szoros vereséget a vesztesek instabil hierarchiának érzékelik, ami a vesztesek T szintjének növekedésével - vagy legalábbis kisebb mértékű csökkenésével - jár (ZILIOLI és mtsai, 2014).

\section{Korlátok}

A jelen kutatás korlátai miatt az eredményeket érdemes némi fenntartással kezelni. Mivel néhány változót nem manipuláltunk kísérletileg (például a versengés kimenetele, pontkülönbség stb.), ezért az összefüggéseket nem tekinthetjük okokozati jellegűnek, kivéve azokat az eredményeket, ahol az időbeliség logikailag meghatározza az eredmények kauzális természetét, mint például a játék előtti $T$ szint és a későbbi versengő teljesítmény korrelációi. Annak ellenére, hogy az a priori powerelemzés szerint megfelelő méretű mintával dolgoztunk, valószínű, hogy a jutalmazás hatásait a pszichofiziológiai és hormonális változásokra a statisztikai erő hiánya miatt nem tudtuk kimutatni. Továbbá elképzelhető, hogy a jutalmazási feltételekben túl kicsi volt az eltérés, és ezért nem sikerült megtalálni az elvárt pszicho-biológiai változásokat, habár a játék előtt az egyenlőtlen jutalom csoportban lévők nagyobb izgatottságot mutattak, mint az egyenlő jutalom csoportban lévők.

További korlátot jelenthet, hogy a versengő helyzet egy agresszív természetű játék volt. Egy meta-analízis azonban azt találta, hogy az agresszió embereknél nem függ össze konzisztensen a T szint változásaival (ARCHER, 2006). Továbbá egy, az átlagosnál jóval nagyobb mintát használó kutatás $(\mathrm{N}=237)$ nem talált bizonyítékot arra, hogy egy agresszív videojáték (boksz) magasabb T szinttel járna, mint egy nem agresszív videojáték (röplabda) (CARRÉ, CAMPBELL, LOZOYA, GOETZ és WELKER, 2013). 


\section{Konklúzió}

Legjobb tudomásunk szerint ez az első kutatás, ami a jutalmazás hatását vizsgálta a T szint változásaira egy készség és erőfeszítés alapú versengés során. Habár nem sikerült kimutatni a jutalmazás hatását a $T$ szintre, a jövőbeli kutatásoknak érdemes lehet a témát tovább vizsgálnia nagyobb jutalomkülönbséggel, illetve nagyobb mintán. A kutatás jelentős eredménye, hogy a hiperversengő attitűdöt sikerült a T szint változásaival összefüggésben értelmezni a veszteseknél. Ez az eredmény megfelel a státuszinstabilitás-elmélet által leírt változásoknak. Ezt az elméletet támasztotta alá továbbá a versengő teljesítmény összefüggése a T szinttel. Ezek a változások megmutatták, hogy amennyiben a győztes státusza instabil - akár a vesztes hiperversengő attitűdje, akár a versengés szorossága miatt -, a vesztes megnövekedett tesztoszteronszintet mutathat.

\section{IRODALOM}

ARCher, J. (2006). Testosterone and human aggression: An evaluation of the challenge hypothesis. Neuroscience and Biobehavioral Reviews, 30(3), 319-345.

Bateup, H. S., Booth, A., Shirtcliff, E. A., \& Granger, D. A. (2002). Testosterone, cortisol, and women's competition. Evolution and Human Behavior, 23(3), 181-192.

Brage, S., Brage, N., Franks, P. W., Ekelund, U., \& Wareham, N. J. (2005). Reliability and validity of the combined heart rate and movement sensor Actiheart. European Journal of Clinical Nutrition, 59(4), 561-570.

Carré, J. M., Campbell, J. A., Lozoya, E., Goetz, S. M. M., \& Welker, K. M. (2013). Changes in testosterone mediate the effect of winning on subsequent aggressive behaviour. Psychoneuroendocrinology, 38(10), 2034-2041.

Costa, R., \& SAlvador, A. (2012). Associations between success and failure in a face-to-face competition and psychobiological parameters in young women. Psychoneuroendocrinology, 37(11), 1780-1790.

Dabbs, J. M., De La Rue, D., \& Williams, P. M. (1990). Testosterone and occupational choice: Actors, ministers, and other men. Journal of Personality and Social Psychology, 59(6), 1261-1265.

EDwards, D. A. (2006). Competition and testosterone. Hormones and Behavior, 50(5), 681683.

Eisenegger, C., Haushofer, J., \& Fehr, E. (2011). The role of testosterone in social interaction. Trends in Cognitive Sciences, 15(6), 263-271.

Faul, F., Erdfelder, E., Lang, A.-G., \& Buchner, A. (2007). G*Power 3: A flexible statistical power analysis program for the social, behavioral, and biomedical sciences. Behavior Research Methods, 39(2), 175-191.

FÜlÖP M., SzŐLlŐS P., SzŐNYI G., \& TelCS A. (1999). IBS study - első eredmények. In I. Forgach, T. Kun, \& A. Telcs (Eds.), Annales of the International Business School (157172). Budapest: Akadémiai Kiadó.

Gladue, B. A., Boechler, M., \& McCaul, K. D. (1989). Hormonal response to competition in human males. Aggressive Behavior, 15(6), 409-422. 
Gonzalez-Bono, E., Salvador, A., Ricarte, J., Serrano, M. A., \& Arnedo, M. (2000). Testosterone and attribution of successful competition. Aggressive Behavior, 26(3), 235240.

Harrison, L. K., Denning, S., \& Easton, H. (2001). The effects of competition and competitiveness on cardiovascular activity. Psychophysiology, 38, 601-606.

Hayes, A. F. (2013). Introduction to Mediation, Moderation, and Conditional Process Analysis: A Regression-based Approach. New York: The Guilford Press.

KeSELMAN, H. J. (1998). Testing treatment effects in repeated measures designs: An update for psychophysiological researchers. Psychophysiology, 35(4), 470-478.

Malik, M., Bigger, J. T., Camm, A. J., Kleiger, R. E., Malliani, A., Moss, A. J., \& SCHWARTZ, P. J. (1996). Heart rate variability standards of measurement, physiological interpretation, and clinical use. European Heart Journal, 17(3), 354-381.

Mazur, A. (1985). A biosocial model of status in face-to-face primate groups. Social Forces, 64(2), 377-402.

Mazur, A., \& Boоth, A. (1998). Testosterone and dominance in men. Behavioral and Brain Sciences, 21(3), 353-363.

Mazur, A., Bоотh, A., \& Dabbs Jr., J. M. (1992). Testosterone and chess competition. Social Psychology Quarterly, 55(1), 70-77.

Mazur, A., \& Lamb, T. A. (1980). Testosterone, status, and mood in human males. Hormones and Behavior, 14(3), 236-246.

Mazur, A., Shelley, G., Tharp, G., \& Kittok, R. (1989). Testosterone, and winning and losing in human competition. Hormones and Behavior, 23(4), 556-571.

Mazur, A., Susman, E. J., \& Edelbrock, S. (1997). Sex difference in testosterone response to a video game contest. Evolution and Human Behavior, 18(5), 317-326.

McCaul, K., Gladue, B., \& Joppa, M. (1992). Winning, losing, mood, and testosterone. Hormones and Behavior, 26, 486-504.

Menta, P. H., \& Josephs, R. A. (2006). Testosterone change after losing predicts the decision to compete again. Hormones and Behavior, 50(5), 684-692.

Neave, N., \& Wolfson, S. (2003). Testosterone, territoriality, and the "home advantage." Physiology and Behavior, 78(2), 269-275.

Richter, M., \& Gendolla, G. H. E. (2007). Incentive value, unclear task difficulty, and cardiovascular reactivity in active coping. International Journal of Psychophysiology, 63(3), 294-301.

Richter, M., \& Gendolla, G. H. E. (2009). The heart contracts to reward: Monetary incentives and preejection period. Psychophysiology, 46(3), 451-457.

Russell, J. A., Weiss, A., \& Mendelsohn, G. A. (1989). Affect Grid: A single-item scale of pleasure and arousal. Journal of Personality and Social psychology, 57(3), 493-502.

Ryckman, R. M., Hammer, M., Kaczor, L. M., \& Gold, J. A. (1990). Construction of a hypercompetitive attitude scale. Journal of Personality Assessment, 55(3-4), 630-639.

Ryckman, R. M., Hammer, M., Kaczor, L. M., \& Gold, J. A. (1996). Construction of a Personal Development Competitive Attitude Scale. Journal of Personality Assessment, 66(2), 374-385.

Ryckman, R. M., Thornton, B., \& Butler, J. C. (1994). Personality correlates of the Hypercompetitive Attitude Scale: Validity tests of Horney's theory of neurosis. Journal of Personality Assessment, 62(1), 84-94. 
SAlvador, A., \& Costa, R. (2009). Coping with competition: neuroendocrine responses and cognitive variables. Neuroscience and Biobehavioral Reviews, 33(2), 160-170.

Salvador, A., Suay, F., González-Bono, E., \& Serrano, M. A. (2003). Anticipatory cortisol, testosterone and psychological responses to judo competition in young men. Psychoneuroendocrinology, 28(3), 364-375.

Schultheiss, O. C., \& Rohde, W. (2002). Implicit power motivation predicts men's testosterone changes and implicit learning in a contest situation. Hormones and Behavior, 41(2), 195-202.

Stanton, S. J., Liening, S. H., \& Schultheiss, O. C. (2011). Testosterone is positively associated with risk taking in the Iowa Gambling Task. Hormones and Behavior, 59(2), 252-256.

Suay, F., Salvador, A., González-Bono, E., Sanchis, C., Martinez, M., MartinezSANCHIS, S., \& MONTORO, J. B. (1999). Effects of competition and its outcome on serum testosterone, cortisol and prolactin. Psychoneuroendocrinology, 24(5), 551-566.

VAN ANDERS, S. M., \& WATSON, N. V. (2007). Effects of ability- and chance-determined competition outcome on testosterone. Physiology and Behavior, 90(4), 634-642.

Van der Meij, L., Buunk, A. P., Almela, M., \& Salvador, A. (2010). Testosterone responses to competition: The opponent's psychological state makes it challenging. Biological Psychology, 84(2), 330-335.

Wingfield, J., Hegner, R., JR, A. D., \& Ball, G. (1990). The "challenge hypothesis:" Theoretical implications for patterns of testosterone secretion, mating systems, and breeding strategies. American Naturalist, 136(6), 829-846.

Wulfert, E., Franco, C., Williams, K., Roland, B., \& Maxson, J. H. (2008). The role of money in the excitement of gambling. Psychology of Addictive Behaviors, 22(3), 380-390.

Zilioli, S., Mehta, P., \& WAtson, N. V. (2014). Losing the battle but winning the war: Uncertain outcomes reverse the usual effect of winning on testosterone. Biological Psychology, 103, 54-62.

\title{
THE EFFECT OF REWARD ON SALIVARY TESTOSTERONE LEVEL AND PERFORMANCE IN YOUNG ADULT MALES DURING COMPETITION: THE ROLE OF HYPERCOMPETITIVENESS
}

\author{
NAGY, TAMÁS - KOVÁCS J., KRISZTINA - POLYÁK, ÁGNES - HARMAT, LÁSZLÓ - \\ BÁRDOS, GYÖRGY - FÜLÖP, MÁRTA
}

Prior research has shown that in the context of competition, larger rewards are associated with amplified physiological arousal. Yet, few studies examined the effect of reward on testosterone (T) level, although this hormone has been shown to respond to competitive situations and status shifts. The present study investigated salivary $T$ level, physiological arousal (heart rate and heart rate variability), changes during competition in young males $(N=40$, mean age $=21.7 \pm 2.3$ years $)$. Participants competed in pairs in a video game, whereby they could win or lose - according to skill and effort. According to random grouping, pairs were either rewarded equally or the winner gained more monetary reward than the loser (unequal reward). Apart from the physiological and endocrine assessments, 
questionnaires provided information about competitive attitudes (hypercompetitiveness, and "personal development competitive attitude") and mood changes through the competition. Results yielded that both conditions increased subjective and cardiac arousal, but reward conditions had not influenced $T$ response; $T$ increased only in hypercompetitive losers. Competitive performance was correlated to $T$ level and $T$ level change in both winners and losers, supporting the observation that competitive performance and $T$ level can be in a reciprocal relationship. These findings are consistent with the status instability hypothesis.

Key words: biosocial theory of status, challenge hypothesis, competitiveness, heart rate, monetary reward, performance, testosterone, status instability hypothesis 